\title{
Fungicide Application for Late Blight Management: A Boom Attached to a Center Pivot Irrigation System
}

\author{
Brad Geary and Dennis A. Johnson, Department of Plant Pathology, Washington State University, Pullman \\ 99164-6430; Philip B. Hamm, Department of Botany and Plant Pathology, Hermiston Agricultural Research and \\ Extension Center, Oregon State University, Hermiston 97838; and Thomas F. Cummings, Department of Plant \\ Pathology, Washington State University
}

\begin{abstract}
Geary, B., Johnson, D. A., Hamm, P. B., and Cummings, T. F. 1999. Fungicide application for late blight management: A boom attached to a center pivot irrigation system. Plant Dis. 83:512515 .

Chlorothalonil was applied to commercial potato fields of cvs. Russet Norkotah and Russert Burbank in replicated trials through either a center-pivot irrigation system or a spray-boomattached-to-the-pivot system. Water rates were 26,192 and 675 liters/ha for the center pivot and attached boom, respectively. Three crop canopy levels were sampled within $2 \mathrm{~h}$ and again after 6 days following fungicide applications made at 7-day intervals. Efficacy of the two application methods was tested by inoculation of individual excised leaves with an isolate of strain US- 1 or US-8 of Phytophthora infestans and by chemical residue analysis. Severity of late blight did not differ between the two fungicide application methods $2 \mathrm{~h}$ after application but, after 6 days, disease severity was significantly less on leaves where chlorothalonil was applied by the attached boom. Fungicide residues were three times higher on leaves where chlorothalonil was applied by the attached boom than with the center-pivot system. Significantly more disease occurred on fungicide-treated and non-treated leaves inoculated with the US-8 than the US-1 strain. Severity of late blight on inoculated leaves was inversely related to the amount of chlorothalonil residue on leaves.
\end{abstract}

Potatoes, Solanum tuberosum, are grown on approximately 65,000 ha in the Columbia Basin of Washington and Oregon under center-pivot sprinkler irrigation systems. This semiarid region produces approximately $20 \%$ of the U.S. potato crop. Epidemics of late blight, caused by Phytophthora infestans, have occurred regularly in irrigated fields in the Columbia Basin since 1990. The population of $P$. infestans in the Basin is comprised of recently introduced strains that are more aggressive on potato than the previous clonal strain $(17,18)$.

Management of late blight in this region is based on sanitation practices, which include the use of disease-free seed and destruction of tuber refuse and volunteer potato plants, irrigation management, and timely applications of fungicides (11). Total cost of managing late blight in the Columbia Basin in 1995 was estimated at $\$ 30$ million (12).

Corresponding author: D. A. Johnson

E-mail: DJOHNSN@wsu.edu

PPNS No. 0282, Department of Plant Pathology, College of Agriculture and Home Economics Research Center, Project No. 0678, Washington State University, Pullman 99164-6430.

Accepted for publication 8 March 1999.

Publication no. D-1999-0412-02R

(C) 1999 The American Phytopathological Society
Ground application sprayers are used on less than $3 \%$ of the potato production land and only before row closure. For the remaining area, and during the rest of the growing season, fungicide applications are made by aircraft and by chemigation through center-pivot sprinkler irrigations systems (10). In Washington in 1995, 75\% of the applications were made by air and $25 \%$ by chemigation (12); however, the percentage by chemigation has increased the last few years because it is less expensive than air application. A disadvantage of chemigation is that the fungicide is diluted in a large volume of irrigation water (usually 48,000 to 58,400 liters/ha) used in application, and less material is retained on the plant foliage $(3,7)$.

In 1996 and 1997, a spray boom was attached to a center-pivot sprinkler irrigation system that allowed application of fungicides in low volumes of water. The application system was engineered to apply fungicide evenly along the length of the pivot using water independent of the irrigation water. Other workers have also applied fungicides through booms attached to a center-pivot irrigation system, but designs and results have varied $(2,19)$. The purpose of this study was to evaluate the effectiveness of an attached boom developed in central Washington in comparison with chemigation through the center-pivot irrigation system in applying fungicide for the control of late blight.

\section{MATERIALS AND METHODS}

Tests were conducted in fields of commercially grown potato cv. Russet Norkotah in 1996 and cv. Russet Burbank in 1997. Cv. Russet Norkotah is more susceptible to late blight than cv. Russet Burbank (8). The former has a determinate and the latter an indeterminate growth habit. The fields were 15.5 ha in size in 1996 and 50 ha in 1997; both fields contained a Quincy loamy sand soil and were near George, Washington. Certified potato seed was planted each year in early April and the crop was fertilized, irrigated, and cultured using recommended practices $(1,5)$.

A spray boom was attached along the length of the center-pivot systems in the two fields. Flood-jet 0.5-mm nozzles (Tee Jet Spraying System Co., Chaniotte RD., Wheaton, IL), spaced $165 \mathrm{~cm}$ apart, and a system of solenoid pressure-regulated valves that regulated flow and pressure at 170 to $205 \mathrm{kPa}$ to the spray nozzles, were developed and installed by engineers at Quincy Farm Chemical (Quincy, WA) and A \& L Supply (Othello, WA). A trailer was designed to be a stand-alone service center for the necessary water, chemical pumps, tanks, and valves. The key to this system was the introduction of the fungicide into the water system as it was required by the nozzles. Sections of the attached boom only sprayed as that section of the pivot moved between wheels, creating a sequential water demand along the pivot. A precision metering pump developed by Ozawa $\mathrm{R} \& \mathrm{D}$ (Ontario, OR) was used because of its ability to introduce chemicals in direct relation to water movement as recorded by an inline flow meter.

Bravo 720 (chlorothalonil; formerly ISK Biosciences, presently Zeneca Ag Products, Wilmington, DE) was used in 1996 and Bravo WS (chlorothalonil) in 1997. Fungicide was applied at 1.75 liters/ha, either through the irrigation system with 26,192 liters/ha (0.10 in/acre) of water, or through the attached boom with 675 liters/ha (73 gal/acre) of water. Plots covered the total area of the field. Plots for fungicide treatments were wedge-shaped sections of the circle and were equal in size. The two fungicide treatments each year were randomized and arranged in three blocks (replications). An area ( 2.4 by $2.4 \mathrm{~m}$ ) in each block was covered with a plastic tarp during the fungicide applica- 
tions for a non-treated control. Three applications of each treatment were made each year at 7-day intervals.

Separate leaf samples were collected for the challenge inoculation and chlorothalonil residue analysis within $2 \mathrm{~h}$ and after 6 days following each application. Three subsamples of leaves were randomly collected from the upper, middle, and lower levels of the canopy in three equidistant subsections of the treated plots in 1996 and in each of the treated plots in 1997. Subsamples from the three canopy levels were taken from the non-treated controls at each sample time.

Collected samples were placed in sealed plastic bags in a cooler and taken to the laboratory for inoculation. Leaf petioles were placed in test tubes $(16 \mathrm{~mm}$ in diameter by $150 \mathrm{~mm}$ in height) containing 23 $\mathrm{ml}$ of a 6.5 -g/liter sucrose solution with $0.435 \mathrm{~g} /$ liter of Peters 20-20-20 N-P-K (W. R. Grace and Co., Fogelsville, PA). Leaves then were sprayed until wet (approximately $0.3 \mathrm{ml} /$ leaflet) with a $10,000-\mathrm{ml}$ sporangial suspension of either isolate Fi2 (US-1) or 584 (US-8) of P. infestans in 1996, and only with isolate 584 in 1997. A hand-held mini-sprayer (Sears Roebuck \& Co., Seattle) and a vacuum pump at $35 \mathrm{kPa}$ were used to apply the inoculum. Leaves were placed in a mist chamber at 17 to $22^{\circ} \mathrm{C}$ for $24 \mathrm{~h}$ and then placed in a greenhouse. Temperature in the greenhouse ranged from 18 to $24^{\circ} \mathrm{C}$ during the day and 10 to $18^{\circ} \mathrm{C}$ at night. The photoperiod was more than $14 \mathrm{~h}$ without supplemental lighting. The percentage of leaf area with late blight symptoms was estimated 7 days after inoculation (9). Sporangia for inoculation were produced on excised leaves of $\mathrm{cv}$. Russet Burbank placed in the sucrose-nutrient solution and incubated at $18^{\circ} \mathrm{C}$ and a relative humidity near $100 \%$.

Samples for chlorothalonil residue analysis consisted of leaf discs (diameter, 5 $\mathrm{mm}$ ) from five terminal leaflets at each sampling location. Samples were placed in vials, frozen, and then shipped for analysis (Ricerca, Inc., Painesville, OH). Levels of chlorothalonil were then determined by gas chromatography, using electron capture detection. Toluene was used as an extraction medium.

Disease severity data were analyzed by analysis of variance using the GLM procedure of SAS (SAS Institute, Inc., Cary, NC). Fisher's protected least significant difference at $P=0.05$ was used to compare treatment means. The relationship of severity of late blight on assayed detached leaves inoculated with isolate 584 (US-8; dependent variable) and the quantity of chlorothalonil residue on leaves (independent variable) was investigated using linear regression with data collected in 1996 and 1997. Chlorothalonil residue levels were $\log$ transformed and data were analyzed using the UNIVARIATE and REG procedures of SAS (SAS Institute, Inc.).

\section{RESULTS}

Severity of late blight was significantly greater $(P<0.01)$, regardless of treatment, when leaves were inoculated with isolate

584 (US-8) than when inoculated with isolate Fi2 (US-1; Table 1). There was not a significant $(P>0.05)$ isolate by fungicide application interaction; therefore, data for

Table 1. Mean percentage of leaf area with lesions when foliage of cv. Russet Norkotah potato was treated with Bravo 720 through a center pivot or an attached boom, or not treated with fungicide, and then inoculated with strains US 8 or US 1 of Phytophthora infestans in $1996^{\mathrm{z}}$

\begin{tabular}{|c|c|c|c|c|}
\hline \multirow[b]{2}{*}{ Treatment } & \multicolumn{2}{|c|}{ Strain US 8} & \multicolumn{2}{|c|}{ Strain US 1} \\
\hline & $2 \mathrm{~h}$ & 6 days & $2 \mathrm{~h}$ & 6 days \\
\hline Center pivot & $9 a$ & $48 \mathrm{~b}$ & $5 \mathrm{a}$ & $28 \mathrm{~b}$ \\
\hline Attached boom & $9 a$ & $35 \mathrm{a}$ & $5 \mathrm{a}$ & $17 \mathrm{a}$ \\
\hline Non-treated & $77 \mathrm{~b}$ & $83 \mathrm{c}$ & $50 \mathrm{~b}$ & $54 \mathrm{c}$ \\
\hline
\end{tabular}

${ }^{\mathrm{z}}$ Values are means of four subsamples and three replications. Means of strain US- 8 are significantly greater $(P \leq 0.01)$ than those of corresponding US-1 means according to single degree of freedom contrasts. Values within a column followed by the same letter are not significantly different at $P=$ 0.05 according to Fisher's protected least significant difference. Collections were taken within $2 \mathrm{~h}$ after application or 6 days after application.

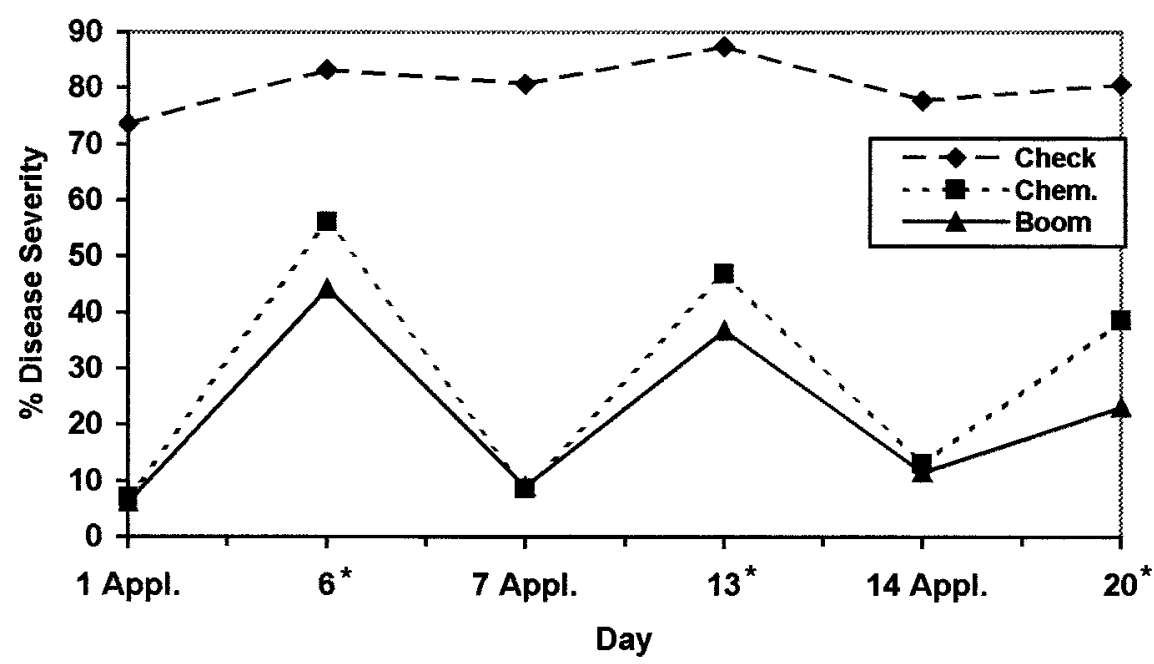

Fig. 1. Mean percentage of potato leaf tissue with late blight symptoms in laboratory leaf assays after Bravo 720 was applied on three dates to a commercial field of cv. Russet Norkotah potatoes through chemigation (26,192 liters/ha), an attached boom (675 liters/ha), and no chemical control in 1996.* indicates that disease severities were significantly different $(P<0.05)$ between the two application methods on days 6,13 , and 20. Disease severities of the two fungicide treatments were significantly less $(P<0.05)$ than the non-treated control leaves on all sampling dates.

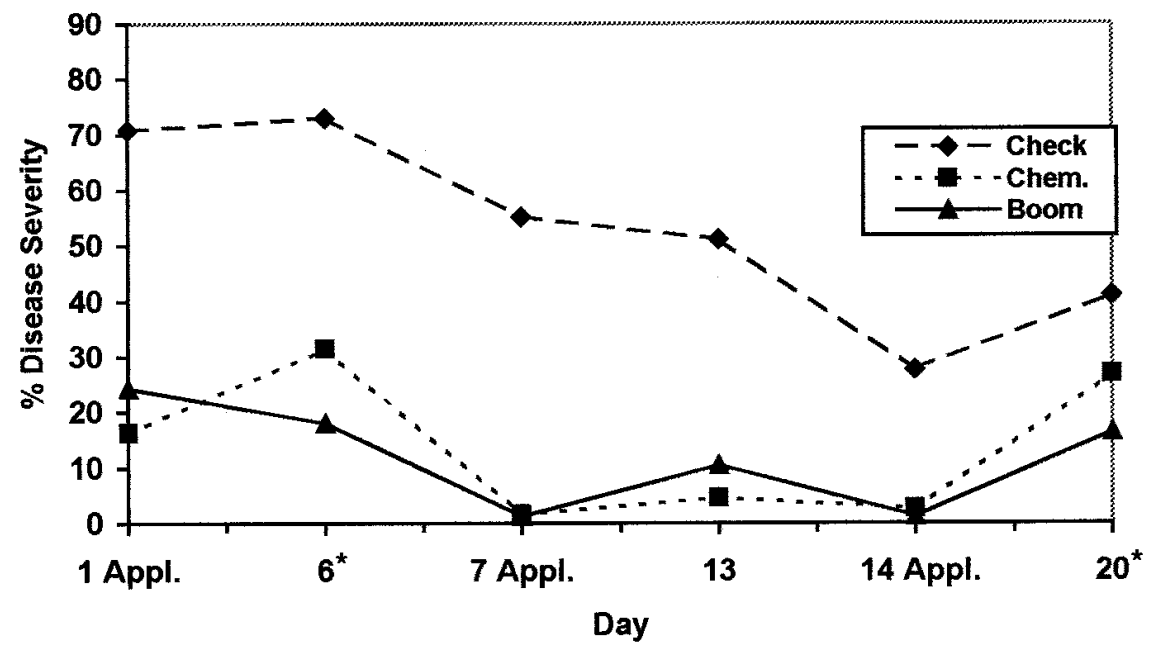

Fig. 2. Mean percentage of potato leaf tissue with late blight symptoms in laboratory leaf assays after Bravo WS was applied on three dates to a commercial field of cv. Russet Burbank potatoes through chemigation (26,192 liters/ha), an attached boom (675 liters/ha), and no chemical control in 1997. * indicates that disease severities were significantly different $(P<0.05)$ between the two application methods on days 6 and 20. Disease severities of the two fungicide treatments were significantly less $(P<0.05)$ than the non-treated control leaves on all sampling dates. 
the two strains were combined for comparison of the application methods. Disease severity of samples collected within 2 $\mathrm{h}$ of the three fungicide applications were combined for analysis, and data collected 6 days after the three applications were combined because data within a time after application were not significantly different $(P$ $>0.05)$. Severity of late blight was significantly less $(P \leq 0.05)$ on leaves treated with fungicide than on leaves not treated with fungicide both years (Table 1, Figs. 1 and 2).

In 1996, severity of late blight was significantly less $(P \leq 0.05)$ on leaves from plants where chlorothalonil was applied by the attached boom than by chemigation 6 days after each fungicide application, but not within $2 \mathrm{~h}$ after fungicide application (Fig. 1). In 1997, severity of late blight was significantly less $(P \leq 0.05)$ on leaves from plants where chlorothalonil was applied by the attached boom than by chemigation 6 days after the first and third applications, but not the second application (Fig. 2). Severity of late blight did not differ significantly $(P>0.05) 2 \mathrm{~h}$ after any of the three applications. In both 1996 and 1997, late blight severity did not differ significantly $(P>0.05)$ among the three canopy levels $2 \mathrm{~h}$ after fungicide applications from either chemigation or the attached boom. In both years, disease severity was significantly greater $(P \leq 0.05)$ on the upper than lower leaves 6 days after chemigation and one of two years when fungicide was applied through the attached boom (Table 2).
Chlorothalonil residues were significantly higher $(P \leq 0.05)$ in each collection period and year where chlorothalonil was applied by the attached boom than when applied by the pivot system (Table 3). Significantly more chlorothalonil was deposited in the upper than middle and lower canopies after application by the attached boom. Fewer differences were observed among canopy levels when the fungicide was applied by chemigation (Table 3).

Severity of late blight significantly decreased $(\mathrm{P} \leq 0.001)$ as chlorothalonil residue increased (Figs. 3 and 4). Coefficients of determination were 0.65 in 1996 and 0.60 in 1997. The estimated level of chlorothalonil required to prevent infection on assayed leaves was $1.63 \mu \mathrm{g} / \mathrm{cm}^{2}$ of leaf tissue with a $95 \%$ confidence interval of 1.1 to $2.7 \mu \mathrm{g} / \mathrm{cm}^{2}$ in 1996 and $1.35 \mu \mathrm{g} / \mathrm{cm}^{2}$



Fig. 3. Scatter diagram showing relationship between chlorothalonil residue and severity of late blight on separate leaf samples taken from the same plots in 1996. with a $95 \%$ confidence interval of 0.9 to $1.9 \mu \mathrm{g} / \mathrm{cm}^{2}$ in 1997 . The estimated amount of chlorothalonil required to prevent infection of $P$. infestans on leaves over all collections decreased from the top to lower canopies both years (Table 4).

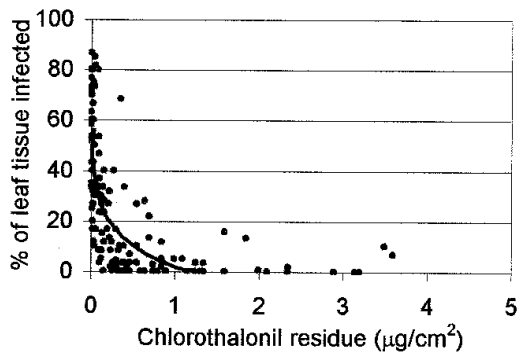

Fig. 4. Scatter diagram showing relationship between chlorothalonil residue and severity of late blight on separate leaf samples taken from the same plots in 1997

Table 4: Estimated quantity of chlorothalonil needed to give a zero percentage of late blight severity at three canopy levels of potato leaves of cv. Russet Norkotah in 1996 and Russet Burbank in 1997z

\begin{tabular}{lcc}
\hline & \multicolumn{2}{c}{ Chlorothalonil } \\
\cline { 2 - 3 } Canopy level & $\mathbf{1 9 9 6}$ & $\mathbf{1 9 9 7}$ \\
\hline Upper & 3.2 & 2.3 \\
Middle & 1.4 & 1.3 \\
Lower & 0.6 & 0.9 \\
\hline
\end{tabular}

${ }^{\mathrm{z}}$ Chlorothalonil measured in $\mu \mathrm{g} / \mathrm{cm}^{2}$. Values are means of 152 samples in 1996 and 136 samples in 1997.

Table 2. Mean severity of late blight on leaves from the top, middle and lower potato canopy two hours and six days after chlorothalonil was applied either by chemigation or through a spray boom attached to a center irrigation $\operatorname{pivot}^{y}$

\begin{tabular}{|c|c|c|c|c|c|c|c|c|}
\hline \multirow[b]{3}{*}{ Canopy level } & \multicolumn{4}{|c|}{1996} & \multicolumn{4}{|c|}{1997} \\
\hline & \multicolumn{2}{|c|}{ Boom } & \multicolumn{2}{|c|}{ Chemigation } & \multicolumn{2}{|c|}{ Boom } & \multicolumn{2}{|c|}{ Chemigation } \\
\hline & $2 \mathrm{~h}$ & 6 days & $2 \mathrm{~h}$ & 6 days & $2 \mathrm{~h}$ & 6 days & $2 \mathrm{~h}$ & 6 days \\
\hline Upper & $8.7 \mathrm{a}$ & $39.3 \mathrm{a}$ & $10.0 \mathrm{a}$ & $57.0 \mathrm{a}$ & $5.1 \mathrm{a}$ & $29.4 \mathrm{a}$ & $5.8 \mathrm{a}$ & $28.5 \mathrm{a}$ \\
\hline Middle & $8.1 \mathrm{a}$ & $30.1 \mathrm{a}$ & $8.5 \mathrm{a}$ & $48.6 \mathrm{ab}$ & $1.2 \mathrm{a}$ & $11.4 \mathrm{~b}$ & $3.3 \mathrm{a}$ & $20.0 \mathrm{ab}$ \\
\hline Lower & $11.6 \mathrm{a}$ & $37.2 \mathrm{a}$ & $9.1 \mathrm{a}$ & $39.4 \mathrm{~b}$ & $13.0 \mathrm{a}$ & $4.4 \mathrm{~b}$ & $7.0 \mathrm{a}$ & $14.4 \mathrm{~b}$ \\
\hline Mean & 9.0 & $35.1^{\mathrm{z}}$ & 9.2 & 48.3 & 7.0 & 15.1 & 5.7 & 21.0 \\
\hline
\end{tabular}

y Values are means of nine subsamples and three replications in 1996 and three subsamples and three replications in 1997. Values followed by the same letter are not significantly different $(P=0.05)$ according to Fisher's protected least significant difference.

${ }^{\mathrm{z}}$ Mean significantly different $(P \leq 0.05)$ than mean of corresponding sampling period $(2 \mathrm{~h}$ or 6 days) of the chemigation according to a single degree of freedom contrast.

Table 3. Mean quantity of chlorothalonil residue on leaves from the top, middle and lower potato canopy two hours and six days after the fungicide was applied either by chemigation or through a spray boom attached to a center irrigation pivot ${ }^{y}$

\begin{tabular}{|c|c|c|c|c|c|c|c|c|}
\hline \multirow[b]{3}{*}{ Canopy level } & \multicolumn{4}{|c|}{1996} & \multicolumn{4}{|c|}{1997} \\
\hline & \multicolumn{2}{|c|}{ Boom } & \multicolumn{2}{|c|}{ Chemigation } & \multicolumn{2}{|c|}{ Boom } & \multicolumn{2}{|c|}{ Chemigation } \\
\hline & $2 \mathrm{~h}$ & 6 days & $2 \mathrm{~h}$ & 6 days & $2 \mathrm{~h}$ & 6 days & $2 \mathrm{~h}$ & 6 day \\
\hline Upper & $3.12 \mathrm{a}$ & $0.47 \mathrm{a}$ & $0.67 \mathrm{a}$ & $0.22 \mathrm{a}$ & $2.69 \mathrm{a}$ & $0.21 \mathrm{~b}$ & $0.51 \mathrm{a}$ & $0.09 \mathrm{~b}$ \\
\hline Middle & $1.60 \mathrm{~b}$ & $0.32 b$ & $0.53 \mathrm{a}$ & $0.17 \mathrm{a}$ & $1.45 \mathrm{~b}$ & $0.68 \mathrm{a}$ & $0.39 \mathrm{~b}$ & $0.13 \mathrm{~b}$ \\
\hline Lower & $0.30 \mathrm{c}$ & $0.24 \mathrm{~b}$ & $0.31 \mathrm{~b}$ & $0.15 \mathrm{a}$ & $0.96 \mathrm{~b}$ & $0.64 \mathrm{a}$ & $0.38 \mathrm{~b}$ & $0.19 \mathrm{a}$ \\
\hline Mean & $1.64^{\mathrm{z}}$ & $0.35^{\mathrm{z}}$ & 0.50 & 0.18 & $1.74^{\mathrm{z}}$ & $0.51^{\mathrm{z}}$ & 0.43 & 0.14 \\
\hline
\end{tabular}

y Chlorothalonil measured in $\mu \mathrm{g} / \mathrm{cm}^{2}$. Values are means of three subsamples and three replications. Values within a column followed by the same letter are not significantly different $(P=0.05)$ according to Fisher's protected least significant difference.

${ }^{\mathrm{z}}$ Mean is significantly different $(P \leq 0.05)$ than mean of corresponding sampling period $(2 \mathrm{~h}$ or 6 days $)$ of the chemigation according to Fisher's protected least significant difference. 


\section{DISCUSSION}

Fungicide application by chemigation appears from observations of disease severities in commercial fields to provide adequate control of late blight in the Columbia Basin of Washington and Oregon (7). However, less fungicide is deposited on potato foliage by chemigation than by aircraft or ground-rig (7). Better control with fungicides is expected with application from the attached boom, particularly 6 days after application, than with chemigation.

Fungicide application was more efficient with the attached-boom than the centerpivot system. Severity of late blight on assayed leaves was less and quantity of fungicide residue was greater on leaves collected from plots treated with the attached-boom than the center-pivot system. Less water was applied with the attached boom. the fungicide would be diluted less and less fungicide would likely be washed from foliage during application. Fungicide loss and redistribution from foliage is influenced by rainfall, time since application, temperature, and canopy position $(4,6,14)$, and also by amount and frequency of sprinkler irrigation. In this study, much of the fungicide applied through the centerpivot system apparently was washed from the plant, and smaller differences in chlorothalonil residue were found among the canopy levels than when applications were made with the boom. Fungicide levels were higher in the upper and middle canopies immediately after an application from the boom. After 6 days, fungicide had been redistributed to the lower leaves or had been washed off, but a relatively high level of fungicide remained on upper and middle leaves to provide protection. However, new growth was not protected. Unprotected foliage that develops during the interval between successive fungicide applications, regardless of application method, is an important factor in managing foliar disease with fungicides (6).

The inoculated leaf assay effectively differentiated between the two fungicide application methods. Results from the assay were significantly related with quantity of chlorothalonil, but quantitatively determining chlorothalonil residue levels was more sensitive than the inoculated-leaf assay. Placing leaf petioles in the sucrosenutrient solution helped maintain turgidity and transpiration of leaves during infection and symptom development. An advantage of the assay is that fungicide applications can be made in the field and then evaluated in the laboratory without introducing inoculum in commercial areas.

A mean chlorothalonil residue threshold of 1.35 to $1.63 \mu \mathrm{g} / \mathrm{cm}^{2}$ leaf was observed when infection did not occur. The estimated quantity of chlorothalonil required to prevent infection was less in 1997 than in 1996, probably because cv. Russet Burbank, used in 1997, is less susceptible to $P$. infestans than cv. Russet Norkotah used in 1996 (8). Our study was not designed to determine a $50 \%$ effective dose $\left(\mathrm{ED}_{50}\right)$ concentration for chlorothalonil. Others, working with Alternaria solani, have determined an $\mathrm{ED}_{50}$ chlorothalonil concentration for inhibition of appressorial formation of $1.2 \mu \mathrm{g} / \mathrm{cm}^{2}$ and for inhibition of lesion formation of $0.6 \mu \mathrm{g} / \mathrm{cm}^{2}$ on tomato foliage inoculated with conidia (16). The chlorothalonil residue threshold reported herein is likely higher than needed for control of late blight in the field because of the rigorous challenge inoculation test used and a high variance in fungicide deposition within the crop canopy (3).

The US- 8 isolate of $P$. infestans was more aggressive than the US- 1 isolate on leaves treated and not treated with fungicide. This study was not designed to detect difference in aggressiveness among strains of $P$. infestans; therefore, only one isolate of each of the two strains was used. However, this study does confirm the increase in aggressiveness of the US-8 strain recently reported $(15,18)$. It also confirms that more frequent applications of protectant fungicide will be needed to suppress epidemics caused by US- 8 as indicated in a simulation study (13).

\section{ACKNOWLEDGMENTS}

We thank the Washington State Potato Commission, the Oregon State Potato Commission, and Zeneca Ag Products (formerly ISK Corp.) for funding; and J. French, A. Greenwalt, D. Spink, and G. Pelter for technical assistance and discussion that led to the development of this project.

\section{LITERATURE CITED}

1. Bishop, G. W., Homan, H. W., Sandvol L. E., and Stoltz, R. L. 1982. Management of Potato Insects in the Western States. West. Reg. Ext. Pub. 64:31.

2. Brenneman, T. B., and Sumner, D. R. 1990. Effects of tractor traffic and chlorothalonil applied via ground sprays or center pivot irrigation systems on peanut diseases and pod yields. Plant Dis. 74:277-279.

3. Bruhn, J. A., and Fry W. E. 1982. A statistical model of fungicide deposition on potato foliage. Phytopathology 72:1301-1305.

4. Bruhn, J. A., and Fry, W. E. 1982. A mathematical model of the spatial and temporal dy- namics of chlorothalonil residues on potato foliage. Phytopathology 72:1306-1312.

5. Dow, A. I., Halvorson, A. R., and Thornton, R. E. 1974. Fertilizer guide to irrigated potatoes. Wash. State Univ. FG-7.

6. Elliott, V. J., and Spurr, H. W., Jr. 1993. Temporal dynamics of chlorothalonil residues on peanut foliage and the influence of weather factors and plant growth. Plant Dis. 77:455460.

7. Hamm, P. B., and Clough, G. H. Comparison of application methods on deposition and redistribution of chlorothalonil in a potato canopy, and potential impact for control of late blight. Plant Dis. 83:441-444.

8. Inglis, D. A., Johnson, D. A., Legard, D. E., Fry W. E., and Hamm, P. B. 1996. Relative resistances of potato clones in response to new and old populations of Phytophthora infestans. Plant Dis. 80:575-578.

9. James, W. C. 1971. An illustrated series of assessment keys for plant diseases, their preparation and usage. Can. Plant Dis. Surv. 52:39-65.

10. Johnson, A. W., Young, J. R., Threadgill, E. D., Dowler, C. C., and Sumner, D. R. 1986 Chemigation for crop production management. Plant Dis. 70:998-1004.

11. Johnson, D. A., Alldredge, J. R., and Hamm, P. B. 1998. Expansion of potato late blight forecasting models for the Columbia Basin of Washington and Oregon. Plant Dis. 82:642645.

12. Johnson, D. A., Cummings, T. F., Hamm P. B., Rowe, R. C., Miller, J. S., Thornton, R. E., Pelter, G. Q., and Sorensen, E. J. 11997. Potato late blight in the Columbia Basin: an economic analysis of the 1995 epidemic Plant Dis. 81:103-106.

13. Kato, M., Mizubuti, E. S., Goodwin, S. B. and Fry, W. E. 1997. Sensitivity to protectant fungicides and pathogenic fitness of clonal lineages of Phytophthora infestans in the United States. Phytopathology 87:973-978.

14. Ko, W. H., Lin, H., and Kunimoto, R. W 1975. A simple method for determining efficacy and weatherability of fungicides on foliage. Phytopathology 65:1023-1024

15. Lambert, D. H., and Currier, A. I. 1997. Differences in tube rot development for North American clones of Phytophthora infestans. Am. Potato J. 74:39-43.

16. Lukens, R. J., and Ou, S. H. 1976 Chlorothalonil residues on tomatoes and protection against Alternaria solani. Phytopathology 66:1018-1022.

17. Miller, J. S., Hamm, P. B., and Johnson, D. A 1997. Characterization of the Phytophthora infestans population in the Columbia Basin of Oregon and Washington from 1992-1995. Phytopathology 87:656-660.

18. Miller, J. S., Johnson, D. A., and Hamm, P. B. 1998. Aggressiveness of isolates of Phytophthora infestans from the Columbia Basin of Washington and Oregon. Phytopathology 88:190-197.

19. Wyman, J. A., Wolgenbach, J. F., Stevenson, W. R., and Binning, L. K. 1986. Comparison of aircraft, ground-rig and center pivot irrigation systems for application of pesticides to potatoes. Am. Potato J. 63:297-314. 